\title{
Organized Crime in Brazilian Prisons: The Example of the PCC
}

\author{
Camila Nunes Dias* and Fernando Salla
}

\begin{abstract}
Federal University of ABC, Center for Study of Violence at the University of São Paulo, São Paulo, Brazil
Abstract: This paper analyses the context of the mass incarceration experienced by Brazil in the last two decades. Alongside other factors, such as the deterioration of the living conditions of the inmates and the shortcomings in the prison management, this favored the emergence and operation of the self-named group Primeiro Comando da Capital (PCC) (First Command of the Capital), within the prison system of the state of São Paulo. It outlines the stages that resulted in the expansion of the PCC, from its creation to the consolidation of its rule over the incarcerated population and analyzes the form acquired by the use of violence by part of this group. Besides the use of official documents, the ethnographic method and interviews with staff and inmates were used. Among the major findings of the research, there is the constitution of the PCC as a centralized instance of mediation and conflict resolution within the prison, a phenomenon that produced a significant reduction in physical violence among prisoners.
\end{abstract}

Keywords: Prison, incarceration, criminal groups, organized crime, violence, Brazil, state of São Paulo.

\section{INTRODUCTION}

In February 2001, in the state of São Paulo, in the southeast region of Brazil, a severe crisis affected the prison system. Approximately 30 state prison facilities rebelled simultaneously, involving 28,000 prisoners, resulting in the deaths of 20 inmates. These incidents were described, by the press, as the 2001 'megarebellion'. They were attributed, by the authorities, to a criminal group that operated inside the prisons, namely the Primeiro Comando da Capital, known by the abbreviation PCC. Despite the severity of the revolt, the resultant deaths, and the shock to the maintenance of order in the prison units, this mega-rebellion did not exceed the boundaries of the prison facilities.

Five years later, from May to August 2006, the state of São Paulo was the stage for one of the largest crises ever experienced in the country in the area of public security. This time, the crisis affected not only the prison system, but also the society at large. There were more than 70 rebellions organized by the PCC in the state prisons. Outside the prisons, this same group instigated hostilities and attacks against ordinary citizens, and particularly against public agents, mainly police officers and penitentiary agents. Bank buildings, supermarkets and police stations were the targets of the assaults (by shotgun fire, incendiary bombs and home-made bombs). Furthermore, public transport vehicles, such as buses and vans, were set on fire. The crisis unfolded in three waves, with a total of 1,325 attacks and 172 deaths. ${ }^{1}$

*Address correspondence to this author at the Department of Sociology, Center for Study of Violence at the University of São Paulo, São Paulo, Brazil; Tel: 5511 3091-4951. Fax: 5511 3091-4950

E-mail: camila.dias00@gmail.com, fersalla@gmail.com

${ }^{1}$ The newspaper O Estado de S. Paulo, May 13, 2007, page C06. The numbers published at the time of the events and those divulged later are significantly divergent.
The main protagonist of these events - the PCC had been formed, in 1993, in a maximum security prison, in the interior of the state of São Paulo, in the city of Taubaté. In less than ten years of existence, this group succeeded in imposing itself over the prison population. It displayed an extraordinary ability to mobilize the prisoners and to organize their actions, with a strong articulation of people inside and outside the prisons, in 2001, and particularly in 2006 . One of the objectives of this paper is to analyze the context of the Brazilian prison, the rampant growth of its incarcerated population in recent decades, and the low organizational capability of the public services in this area, as essential elements in the formation of groups such as the PCC. In parallel to this argument, with respect to the 'failure' of the capability of the authorities to maintain order and discipline in the prisons, this paper intends to describe and analyze the successive stages by which this criminal group consolidated itself. It will discuss the legitimization and obedience processes that it sought to impose on the inmates and how it has articulated relationships of power with the authorities $^{12}$.

The analysis of the establishment of an organized criminal group inside Brazilian prisons and its high ability to control the incarcerated population, as well as its consolidation in the control of many criminal activities outside the prisons can contribute with a reflexive tradition, mainly in the field of sociology, involving not only studies referring to the dynamics and peculiarities of life and conflicts among inmates

\footnotetext{
${ }^{2}$ Besides the use of official documents, the ethnographic method and interviews with staff and inmates were used. However, the interviews could not be recorded and the information collected from the prisoners and prison officials were used throughout the text indirectly.
} 
(Clemmer, 1958; Hayner \& Ash, 1939; Shrag, 1954; Weinberg, 1942), but also to studies specifically directed to the emergence of rebellions and the operation of groups of prisoners in these events (Sykes, 1974 [1958]; Maccormick, 1954; Useem \& Kimball, 1987 and 1991; Artières, 2003; Favard, 1981 and 1987; Adams 1994). Moreover, the analysis that we intend to present can contribute to the field of studies on organized crime (Lampe, 2008; Ziegler, 2003; Lupo, 2002; Fontanaud, 2002; Hagan, 1983; Huff, 1990; Paoli, 2002), by outlining the peculiarity of the structure and the dynamics of a criminal group that originated in the prison system. Furthermore, its operation has expanded to several sectors of illegal trade, particularly drug trafficking. The PCC occupies an important position in the Brazilian setting, with a significant dominance in the distribution of this merchandise - mainly cocaine and marijuana - in the state of São Paulo. However, this analysis of the PCC should not be confused with the treatment of other groups commonly inserted into the organized crime category, such as the mafia, cartels, gangs ${ }^{3}$, etc.

\section{EXPLOSION IN INCARCERATION}

Brazil followed the trend of many countries with a strong increase in the rate of incarceration over the last two decades (Wacquant, 2001; Bauman, 1999; Christie, 1998). In 1993, there were approximately 126,000 inmates, corresponding to a rate of 83.2 prisoners per 100,000 inhabitants. ${ }^{4}$ In 2010 , Brazil had an incarcerated population of approximately 500,000 inmates and was ranked fourth place in the world, after the United States, China and Russia. In 2010, the rate was 253 prisoners per 100,000 inhabitants. In the same year, provisional detentions accounted for $37 \%$ of the incarcerated population. Approximately $7.5 \%$ of those imprisoned were women. ${ }^{5}$

The Brazilian prison system has approximately 300,000 available places resulting in a shortage of about 200,000 places. Since the early 1990 s, there has been a chronic overcrowding that aggravates the harsh living conditions in most Brazilian prisons. In 1992, the Casa de Detenção de São Paulo (the São Paulo

\footnotetext{
${ }^{3}$ There is a vast literature on street gangs and prison gangs (Thasher, 1963; Jacobs, 1974; Jankowski, 2003; Phillips, 2012; Holston, 2009). We do consider that the characterizations usually ascribed to gangs is not suitable to define the PCC. And in result, we chose not to bring to this article a comparative reflection. Our choice was meant to emphasize the specificities of the operation of the PCC in the penitentiary system of São Paulo.

${ }^{4}$ Ministry of Justice, National Penitentiary Department.

${ }^{5}$ Cf. International Centre for Prison Studies, http://www.kcl.ac.uk/schools/ law/research/icps.
}

Detention Center), which housed almost 7,000 prisoners but only had a capacity for approximately 3,200 , staged one of the bloodiest chapters in prison history in Brazil and worldwide. The intervention of the police at the Casa de Detenção de São Paulo resulted in the so-called "Carandiru massacre", when 111 inmates were killed.

In Brazil, there is a single criminal and penal legislation. However, the states are responsible for the organization and maintenance of the prison system. Only recently, in 2006, was a federal penitentiary system established which is still very limited, with less than a thousand available places. The capacity of the states for the allocation of funds for the management of the prison system is quite heterogeneous. It depends partly on the political will of the governors and the economic conditions of the state. There are states in Brazil that can only build or renovate prison units when the federal government transfers funds for this purpose.

The paradoxical phenomenon, in one sense, is that the state of São Paulo, although the richest economically, ${ }^{6}$ with approximately $25 \%$ of the Brazilian population, and with one the most complex and organized prison systems in the country, has been the location of the formation and development, inside its prisons, of one of the most powerful criminal organizations to operate in the country in the last twenty years.

In 2010, São Paulo had approximately 171,000 inmates and a rate of 413 inmates per 100,000 inhabitants. These inmates represented $34 \%$ of the incarcerated population of the country, ${ }^{7}$ and they were distributed among 148 prison units. Especially in the last few decades, the state of São Paulo has been a national reference in terms of investment in the prison system. However, this investment was limited, almost exclusively, to a frantically paced physical expansion of the system. At the end of 1990 , there were 37 prison units, $^{8}$ a number that, in 1994, reached 43 , housing approximately 32,018 inmates. The state governors

\footnotetext{
${ }^{6}$ Accounting for approximately $30 \%$ of the Brazilian GNP. 2006 data from the São Paulo state government at http://www.bibliotecavirtual.sp.gov.br/saopaulodadosestatisticos.php

${ }^{7}$ According to the Ministry of Justice.

${ }^{8}$ These numbers only refer to units belonging to the penitentiary management, firstly under COESPE (Coordenadoria dos Estabelecimentos Penitenciários Coordinator of Penitentiary Facilities) and later under SAP (Secretaria de Administração Penitenciária - Office of Penitentiary Administration). We shall not discuss here the management restructurings that conferred greater powers to either of these institutions.
} 
that followed this period provided continuity and accentuated this trend of expansion of the system. In 1999, for example, under the term of Governor Mário Covas, the penitentiary administration ${ }^{9}$ had 64 units for 47,000 prisoners (Salla, 2007). In 2006, at the end of the term of Governor Geraldo Alckmin, São Paulo's penitentiary structure reached the astonishing figure of 130,814 inmates, ${ }^{10}$ in 144 units. In 2009, the deficit in the state was estimated at 53,558 places. ${ }^{11}$

The unprecedented expansion of the São Paulo prison system was not accompanied by investment in the infrastructure of these facilities and significantly less in the number and qualification of its employees. The employee/inmate ratio, which, in 1994, was 1:2.17, had become 1:4.99, in 2006 (Adorno \& Salla, 2007). Therefore, the growth rate of the incarcerated population was higher than the number of staff employed. If only the number of penitentiary agents is taken in account, who are officially responsible for the custody of the prisoners - even if many of them are allocated administrative or general service functions the mismatch is even more striking, with 1 agent for every 7.3 inmates. $^{12}$

The increase in the incarcerated population, alongside the physical expansion of the system, was also not accompanied by improvements in terms of work and education opportunities, or in welfare services, health care, etc. Simultaneously, the security and law enforcement services did not keep up with the new conditions created by the pressure of mass incarceration and overcrowding.

In short, the accelerated growth of the incarcerated population; the failures in the organization of the prison service; the persistence of the precarious conditions of incarceration for the inmates; and the disastrous police interventions in prisons, such as the Carandiru massacre, in 1992, can be seen as processes that encouraged the formation and expansion of the criminal organizations, also known as factions, in the prison system of São Paulo.

\footnotetext{
${ }^{9}$ Over the same period, the police precincts (police stations and local prisons) housed 31,343 inmates, of which 11,860 had already been convicted.

${ }^{10} \mathrm{In}$ addition to the 13,616 prisoners in the police precincts.

${ }^{11}$ SAP data for June 2010 at www.sap.sp.gov.br

${ }^{12}$ According to data available at the DEPEN website (Departamento Penitenciário - Penitentiary Department), the incarcerated population of São Paulo under the custody of SAP is 164,425 , whereas the total number of penitentiary agents is 22,515 . In order to evaluate the extent of this employee deficit, it has to be taken into consideration that penitentiary agents work in shifts of 12/36 hours. These are divided into four shifts, 2 daytime and 2 at night, which makes the agent/inmate ratio even more disproportionate.
}

The focus of our analysis is the process of expansion of the most important group - in numerical terms and power - from São Paulo - the Primeiro Comando da Capital (PCC). According to estimates of researchers, system employees and prisoners, it controls approximately $90 \%$ of the 148 prison units of the state. In addition to the PCC, other factions operate in São Paulo's prison system. However, they are almost of no importance and some of them have been practically decimated by the PCC. Among the groups that were destroyed by the PCC in its expansion phase were the CDL (Comando Democrático pela Liberdade - Democratic Command for Freedom) and the SS (Seita Satânica - Satanic Sect), which nowadays only presents itself as a religious group and has very few members. There is also the CRBC (Comando Revolucionário Brasileiro da Criminalidade - Brazilian Revolutionary Command of Crime), which commands no more than two prison units; the TCC (Terceiro Comando da Capital - Third Command of the Capital), a dissenter of the PCC that controls only one facility; and lastly, the ADA (Associação dos Amigos dos Amigos - Association of Friends of Friends), which apparently is a branch of its Rio de Janeiro model, but of no importance in São Paulo, having considerable influence in only one prison unit. The remaining units in the São Paulo prison system are controlled by the PCC, except for 5 units that are considered "neutral" These are not controlled by groups and also do not admit the presence of members or ex-members of factions inside their units.

By extending its control over almost the entire São Paulo prison system from the second half of the 1990s, the PCC began to control the illegal activities performed inside and later outside the prison. It also provided basic goods and services to some inmates and their families, supplying groceries, medicines and transport assistance for families visiting their imprisoned relatives. Simultaneously, the PCC imposed itself as a regulatory court of the social relations inside the prison It exercised the role of arbitrator and made decisions in the most diverse forms of social conflicts, as well as participating directly or indirectly in the management of the prison units.

We seek to understand the PCC expansion process through a very specific frame: the type and intensity of the violence exercised by the group over the incarcerated population. As a parameter, we use the rebellions and murders of prisoners, which are taken into consideration not only in quantitative terms but also, overall, from the form used in these events. In this 
connection, we have divided this process into three stages, which suggest distinctive configurations of power that demand diverse forms of the exercise of the violence perpetrated by the PCC. ${ }^{13}$

\section{FIRST STAGE: CONSTITUTION, TERRITORIAL CONQUEST AND ANONYMITY (1993-2001)}

According to its founders, the PCC was created on August 31, 1993, in the annex of the Casa de Custódia de Taubaté (Taubaté Custody Center), a prison unit with the most rigid disciplinary system in the state of São Paulo. Its expansion within the prison system began in 1994, when the founders were transferred to other prison units, and its influence began to be noticed from 1995. The vertiginous increase of the rebellions that culminated with the 'mega-rebellion' of 2001 and the exponential expansion of their duration, with demands that, beyond precise complaints, acquired a structural character, ${ }^{14}$ suggested that significant alterations were occurring in the prison system of São Paulo. In order to exemplify this statement, we considered the number of rebellions in São Paulo ${ }^{15}$ in 1990 (11) and in 1991 (14). In 1993, this number reached the level of 56 events, reaching the peak of 95 cases in 1997 and 73 in 2000. Even considering the limitations of these numbers and some precariousness of the sources, we believe that the vertiginous increase of these events in this period is unequivocal. ${ }^{16}$

Besides the rebellions, there was an increase in the rescue operations ${ }^{17}$ of prisoners, with actions involving sophisticated planning and the use of heavy weaponry. Murders increased inside the prisons. In the state of São Paulo, in 1996, there were 42 homicides among approximately 33,000 inmates in the penitentiary system. This number reached its peak, in 1999, with 117 murders in a population of 53,000 prisoners. The number of spectacular mass breakouts also grew, which demonstrated not only the planning capability of

\footnotetext{
${ }^{13}$ This means that we do not intend to produce a history of the PCC, but to analyze its expansion from this particular point of view. For a description of the emergence, expansion and events involving the PCC, as well as its characters, see the newspapers reports by Jozino (2005), Souza (2006) and Souza (2007).

${ }^{14}$ Among the structural character demands, we highlight the closing down of the Anexo da Casa de Custódia de Taubaté, well known for its ill treatment of inmates and, not by chance, the birth place of thePCC.

${ }^{15}$ The figures on rebellions and rescues up to 2001, reported in this paper, are based on a survey of press material, produced with the cooperation of Alex Martire, from the Núcleo de Estudos da Violência (NEV-USP), whom we gratefully thank for the valuable collaboration.

${ }^{16}$ For a survey of the rebellions and their characteristics (including their duration), in the period 1995-2000, see Adorno \& Salla (2007) and Salla (2001 and 2006).

${ }^{17}$ The rescue of a prisoner differs from a breakout because it relies on the help of third parties outside the prison and usually follows a previously outlined plan and the use of sophisticated weaponry.
}

the PCC but also its corruptive potential. This was made possible by the profits from drug trafficking and other crimes carried out by members of the organization, such as kidnappings and bank robberies. The significant increase of these events indicates that the prison system was undergoing a process of reconfiguration of the relationships of power and of the form of action of the inmates involved with the PCC. ${ }^{18}$

Despite the evidence that a transformation of the actions of the inmates in São Paulo was in progress, that they had acquired more sophistication, articulation and planning, indicating the presence of something unheard of in the state, the São Paulo government refused to acknowledge the existence of the organization. The PCC began slowly to appear in the news in 1995. The press intensified the mention of its existence and operations from 1999. Nevertheless, it was only after the 'mega-rebellion', in February 2001, that the PCC was officially acknowledged by the government. This was at a time when it was already sufficiently structured to organize a simultaneous rebellion in 29 prison units, using something that was becoming the new weapon to be fought by the prison system, namely the mobile phone. During the 'megarebellion', which spread from the Carandiru penitentiary complex - especially in the 'Casa de Detenção' and the 'Penitenciária do Estado' - the face of the PCC was made public by several banners displayed in the rebel units containing not only the name of the faction, but also its numerical symbol 15:3:3 $3^{19}$ and their motto, "peace, justice and freedom". These images were repeatedly exhibited on television and in newspapers worldwide. Their goal had been achieved: to display to society their existence and their organizational capability. This resulted in an unprecedented demoralization of the state government, which had no other choice but to acknowledge its existence and to promptly announce supposed counter-measures.

\section{SECOND STAGE: EXPANSION AND IMPOSITION OF THE DOMINANCE OF THE FACTION (2001-2006)}

The event that occurred in 2001, which publicly exposed the existence of the faction, had two immediate effects. On the one hand, it triggered the

\footnotetext{
${ }^{18}$ Once again, we shall not look closely at the numerical data of these events but, as an example, we can consider the rescues. From 1991 to 1994 , the press recorded only two cases in each one of these years. In 1995, the figure rose to 11 , reaching a peak of 24 cases in 1999 and 25 in 2000.

${ }^{19}$ This symbol refers to the positions in the alphabet of the letters that form the abbreviation PCC. In this case, "P" is in the $15^{\text {th }}$ position and " $\mathrm{C}$ " is in the $3^{\text {rd }}$ position.
} 
repressive response of the state with the creation of the Regime Disciplinar Diferenciado (RDD - Differentiated Disciplinary Regime), ${ }^{20}$ with the building of an extremely modern and sophisticated prison unit destined for the requirements of the regime, the Centro de Readaptação Penitenciária (CRP - Penitentiary Readaptation Center) in the city of Presidente Bernardes, in the interior of the state. On the other hand, the 'mega-rebellion' brought prestige and respect to PCC members, quickly strengthening and stimulating its dissemination in the São Paulo prisons. Reports by several inmates indicate that after the 2001 'mega-rebellion', the baptisms - a type of initiation rite for new members of the organization - were even performed collectively, such was the demand from the prisoners to join the group, especially at the Casa de Detenção de São Paulo. The entry of an enormous number of new members provided the PCC with the reinforcements required for its expansion to new prison units and, significantly, for the consolidation of its control where it was already present. Accordingly, if the first stage is marked by territorial conquest, this second period has the principal characteristics of territorial expansion and the consolidation of its dominance.

Although the violence did not cease in this period, we can observe that there was an alternation between a larger and smaller intensity of the explicit use of force in the prisons, unlike the first stage in which the exacerbated violence was a constant threat. Through multiple and complex relationships with the prison management, the PCC established periods of 'peace' in the prison units. They said they were "waving the white flag", and that any settlement of disputes that resulted in deaths or physical aggression was prohibited. $^{21}$ This peaceful period in the São Paulo prison system included approximately all of 2003 and the first six months of 2004. According to SAP, ${ }^{22}$ there were 8 rebellions and 97 murders of prisoners in 2002; in 2003 there were no rebellions and the number of homicides fell to 27 , as well as four suicides. In 2004 ,

\footnotetext{
${ }^{20}$ The RDD is a far more severe regime for serving a prison term. The inmate is held in an individual cell without television or radio, with only one hour in the open air, no intimate visits, and meetings with legal counsel have to be previously scheduled, among other restrictions.

${ }^{21}$ During our field work, in the second half of 2003 and the first six months of 2004, we witnessed this period of 'peace' in the units controlled by the faction. For more details of this period, see Dias (2008), particularly Chapter 15.

${ }^{22}$ Different to the data presented in the previous item about the 1993-2001 period, based on a survey of press material, the material with respect to the period dealt with here is still not available. Accordingly, we had to rely on official data, which is deficient and not trustworthy. However, because our aim here is more to analyze a trend and less to point out objective and quantitative matters, we believe that the official data, inconsistent as it may be, allows us to observe these oscillations in the temperature of the prison system during this period.
}

there were four rebellions and 29 murders, as well as, curiously, a drastic increase in the number of suicides: $35 .^{23}$ In 2005, there were 13 rebellions, 50 criminal deaths and 14 suicides. Finally, in 2006, 90 rebellions were recorded, ${ }^{24} 35$ murders and 26 suicides. At the end of 2004 and mainly in 2005, the horror shows were replayed once again. The newspapers of the time frequently printed stories of rebel prison units, with their leaders displaying severed heads stuck on poles, ${ }^{25}$ in a clear affront to the government and society.

We realized that during this period there was an oscillation between times of 'war', when the physical violence put into practice by the PCC acquired an eminently expressive character, and other times of 'peace', during which, in addition to the reduction of the number of deaths, as can be noted in the previously presented data, the homicides acquired a less expressive character. In the so-called 'peace' periods, the PCC was not interested in the public demonstration of its strength. This explains why their enemies were executed secretively, by forging suicides - hence the considerable growth of the number of cases of suicides from one year to another. These 'suicides' were performed by hanging and, in this manner, the organization could eliminate those that should be eliminated, without breaking the 'peace' established in the prisons and, possibly, in agreement with the prison management.

Therefore, we understand that the PCC exercises its violent actions in two ways, which vary according to the time and to the diverse and diffuse interests involved in the intricate relationships established with the government. On the one hand, the exercise of violence acquires a clearly explicit form and filled with symbolic elements of a public demonstration of strength and power. On the other hand, the violence acquires a more technical and rational character, losing its expressive and symbolic elements. Instead of being publicized, it is dissimulated.

In consideration of the fact that the use of violence in an explicit, expressive and publicized manner completely characterizes the first expansion period of

\footnotetext{
${ }^{23}$ This matter will be dealt with later.

${ }^{24}$ Included in this total are the 74 rebel units in the episode that became known as the May 2006 crisis.

${ }^{25}$ See, for example, the newspaper Folha de S. Paulo, June 15, 2005, picturing the grotesque images of the rebellion at the Penitenciária de Presidente Venceslau (President Venceslau Penitentiary), which was completely destroyed.
} 
the faction and that it is also present in the second stage, we shall discuss briefly some of its aspects.

According to Balandier (1982), in order to guarantee the maintenance of power, the production of images and the transposition of the conditions of the exercise of the domination and of the positions occupied by the dominators, at a symbolic level, are fundamental. Accordingly, both the foundation of the PCC and the baptism rituals and the forms of execution of enemies and traitors were, for a long time, charged with symbolic elements, which were essential in the consolidation process of its power and in the justification of the exercised violence. In this connection, a double homicide that took place in August 1993 is considered the symbolic mark of the creation of the PCC. It was transformed into a mythical narrative, which is reenacted in the baptism of the new members of the organization and in the many executions of rivals.

For Balandier, "[...] the collective past, elaborated in a tradition, in a custom, is the origin of legitimization. [...] it allows the use of an idealized story, built and rebuilt according to requirements, at the service of current power" (1982, p.7). Therefore, the image of a brotherhood, built from a common experience of privation, suffering, oppression and injustice between the brothers, is reenacted by the baptism ritual and through the reading of the statute that recalls remarkable facts in the history of abuses committed by the authorities in the São Paulo penitentiary system, such as the Carandiru massacre and the constant torture in the annex of the Casa de Custódia de Taubaté.

The executions of rivals or group members, accused of breaking the rules of the organization, were performed in different forms, depending on the context. In some cases, it was necessary to await the favorable opportunity to commit the murder, which had to be performed quickly, in avoid being caught. In these situations, the requirement of practicality and speed in the act of execution eliminated the symbolic element. Nevertheless, whenever the occasion was favorable, the executions ordered by the PCC up to 2006 - with the exception of the aforementioned 'peace' period were filled with symbols that marked and reinforced the power of the organization, especially in rule breaking events, such as the rebellions. Decapitation was one of the marks of the PCC in the executions of the members of other organizations. However, other symbolic forms were recorded: eyes ripped out (traitors), mouths padlocked (informers) and hearts ripped out (enemies).

The importance of publicizing the execution ritual was a result of the exemplary and preventive function that it exercised. The greatest damage of the transgression was not the act in itself, but the disorder in the social body, namely the possibility of a generalization of the offence to the normative code (Girard, 1998) and how more serious it would be and the greater the possibility of its dissemination by the group. Therefore, if the danger is the social disorder, the function of the execution is to impede the propagation of this disorder. Obviously, the reconciliation between the transgressor and the social structure was not the objective of the execution ritual. The idea of correction of the transgressor is absent in this mechanism of power, which is aimed at the future - to impede new transgressions - and not at the past and the transgressor was eliminated and completely destroyed. The terrifying ceremony made the destroyed body of the rival or traitor an emblematic example of the terrible threat hovering over all those who witnessed the execution, discouraging, through the imposition of fear, the repetition of the same mistake (Foucault, 2000a). Furthermore, the execution ritual of a person sentenced by the PCC had the political function of repairing the damaged sovereignty, in that it made the leader's power shine over anyone that, by transgressing the imposed rules, challenged this authority. The failure to react to the provocation would be dishonorable and would demoralize the leader of the organization and, accordingly, threaten his social position. Therefore, the execution was an act of revenge by the leader who, in destroying the transgressor, rebuilds his sovereignty and reaffirms his power (Foucault, 2000a).

By displaying on its flag the Yin and Yang - an oriental symbol that refers to the idea of opposed and complementary energies - as well as the motto "peace, justice and freedom", ${ }^{26}$ the PCC put into practice a whole repertoire of images that sustained the exercise of its power. It referred to the symbolic universe of the struggle of the oppressed against the oppressors, of the identification of all the prisoners in a social narrative marked by injustice, violence and misery, and whose possibility of overcoming this condition is provided precisely by the union of all those around the

\footnotetext{
${ }^{26}$ Recently, probably since 2006 , the term 'equality' has been included in the motto of the PCC.
} 
organization. In the name of this symbolically built ideal, every action could be justified, including violence. This symbolic repertoire put into practice by the faction is fundamental in the understanding of its expansion in the prison system and the consolidation of its control rule during this period. This is because violence alone could not explain such a vertiginous growth and the relative stability conquered by the PCC - inside and also outside the prisons. In short, the essential role of the physical violence in the expansion and the conquest of territories by the PCC is undeniable. However, this violence cannot be dismembered from its symbolic counterpart, which reinforced the power of the faction and, at the same time, legitimized the executions performed in the name an ideal of union and of the formation of a brotherhood. ${ }^{27}$

The consolidation of the power of the PCC power was publicly demonstrated in the second most serious crisis that affected not only the prison system, but also public security in São Paulo. This occurred in May 2006, when 74 prison units rebelled simultaneously, as well as hundreds of attacks against security forces taking place outside the prisons. From then onwards, the PCC was able to transform the manner of exercising violence, taking into account that it had achieved a broad dominance within the prisons and great strength outside them. This became clear when it managed literally to paralyze the largest Brazilian city on a Monday, May 16, 2006, promoting the most serious crisis in Brazilian public security, as previously stated.

\section{THIRD STAGE: MAINTENANCE OF DOMINANCE AND MANAGEMENT OF THE INCARCERATED POPULATION (END OF 2006 TO 2011 ${ }^{28}$ )}

Since the last quarter of 2006, we have witnessed a relative calm in the São Paulo prisons, taking into consideration not only the reduction in rebellions, but also the expressive fall of the numbers of homicides inside the prisons. The symbolic expression of power, which was valid during the expansion process of the faction and the consolidation of its control in the prison system, lost much of this characteristic and the homicides performed by the PCC acquired a more objective aspect, as indicated by the elements that

\footnotetext{
${ }^{27}$ It is not by chance that the members of the PCC are called brothers.

${ }^{28}$ Although the 2006 crisis was more intense in May, there were some confrontations between the PCC and the government in July and August. Up to the time of writing this paper, in April 2011, the described situation had not altered.
}

shall be presented below, which suggest a new method of exercising power. ${ }^{29}$

\section{a. Functional Differentiation}

The functional differentiation process that occurred inside the organization is directly linked to the growth of the PCC inside and outside the prison units and to the diversification of its areas of operation. Inside the prison units, in order for us to remain only in this place, there is the position of disciplina ${ }^{30}$ [discipline], who is the inmate responsible for the maintenance of order in a given sector. Each sector of the prison unit - kitchen, workshop, cleaning, sports - and each wing, has a disciplina, who, as the term suggests, is responsible for the control and maintenance of order in the location. $\mathrm{He}$ is also responsible for the collection of debts usually for drugs -, mediating between the trafficker and the user in debt, in order to avoid that the collection of the debt transforms into a more serious conflict, resulting in death, as was very common in the recent past. There are also inmates called sintonias [tunes], who are responsible for the circulation of information in the prisons, as well as the transmission of the orders and decisions issued by the PCC leadership. ${ }^{31}$ There is also the Piloto Geral or Disciplina geral [general pilot or general discipline], the highest rank in the PCC local hierarchy. As well as these positions, the PCC brothers are distributed in such a way that each cell has one of them - if the number of brothers held in the unit allows this to happen - and he is generally responsible for the maintenance of order in the location ${ }^{32}$. This expresses the capillarity of the power exercised by the Partido [Party $]^{33}$.

However, although there is this hierarchically defined distribution of positions, the occupants of the

\footnotetext{
${ }^{29}$ According to the figures in the DEPEN website, which are provided by the states, in 2007, the São Paulo prison system recorded 1 criminal death, 3 suicides and 34 'natural' deaths; in 2008, the figures were 3, 6 and 41, respectively. The disparity between the aforesaid 'natural' deaths in relation to the other two is conspicuous. This is directly related to the issue that will be discussed next, about the new forms of execution employed by the PCC, which disguise the condition of homicide.

${ }^{30}$ Also named palavra [word].

${ }^{31}$ The sintonia sector, as the group of inmates that perform this role is referred to, is usually formed by prisoners in charge of faxina [cleaning] or boieiro [food delivery]. Faxinas are formally responsible for the cleaning of the inside of the prison unit and boieiros are responsible for bóia [food] delivery to the inmates. As well as these formal functions, however, these inmates perform important roles in the network of power established in the prison because they occupy a privileged position that allows them greater freedom of circulation and more free time, outside the cells. Because these are strategic posts, the PCC designates the people to occupy them. This is because the informal/illegal activities related to the organization are more important than the formal activities that the individual will perform.

${ }^{32}$ Although this is the rule, there are exceptions that depend largely on the status of the brother and on the status of the other occupants of the cell.

${ }^{33}$ Partido [Party] and Comando [Command] are two common forms of selfreference by PCC members. The term Família [Family] is also used.
} 
various command posts (disciplina, sintonia, piloto geral) jointly manage the unit and the decisions taken in the prison are usually collective. Furthermore, these positions are very flexible and easily interchangeable. For example, it is very common for a disciplina de raio to become a disciplina geral and vice-versa. As defined by an interviewed prisoner, "they form a square", i.e., it is a shared management of the prison unit.

\section{b. Grading of the Punishments}

Until recently, death was the main punishment imposed by the organization on its members. However, its development has resulted in a differentiation of the punishments, whose severity depends on the seriousness of the offence. Therefore, the brother who makes mistakes can be excluded permanently from the organization or can be suspended for a specific period of time. This period can vary from 90 days up to two years of suspension. It can happen that, among the excluded brothers, some may be executed; this depends on what happened, the status of the individual and whether or not he poses a threat to the PCC. In relation to the period of suspension, in practical terms, this signifies being unable to baptize new members, being forbidden to trade - especially drugs - and also losing social status before the prison population. This grading of the punishments to the brothers, at the same time that it guarantees the PCC the control over the conduct of its members and the maintenance of discipline, also reinforces the idea of reduction of violence by the organization because murder only takes place in extreme circumstances.

\section{c. Prohibition on Carrying Knives}

This is certainly the change that best expresses the current context of the prison system in São Paulo. Knives, saws and stilettos were always central objects in Brazilian prisons and are directly associated with the insecurity of prison life and were a means of selfprotection. In a sense, this always represented the war of everyone against everyone else, a state of constant belligerence and absence of authority, either legally constituted or established between the inmates themselves. The knife was also a central object in the executions of the PCC, characterized by the decapitation of the victim. However, approximately three years ago, this object was prohibited by the PCC, according to information from the prisoners and employees in the system. Except for the occasions when rebellions or escapes are planned, carrying a knife in PCC prison units results in severe punishment for the guilty individual. When asked about the motives for this prohibition, the inmates interviewed in the course of our research produced the same response: if everyone is a member or companion of the PCC and also if there is an order for the maintenance of peace in the system - i.e. fights and deaths motivated by personal grudges and the settlement of accounts are not allowed - if any problems acquired by individuals should be reported to the local 'authorities', then there is no reason to carry a knife. The prisoner that carries this object will be suspected of plotting something against the PCC or of planning to disobey the order of maintaining the peace in the prisons, as well as not respecting the local leader's authority to resolve interpersonal conflicts. In every case, it is considered a serious offence and results in punishment.

\section{d. Changes in the Manner of Killing}

Since 2006, in agreement with the aforementioned rule, the PCC no longer executes its enemies inside the prisons with attacks from knives or stilettos because 'spilling blood' is prohibited in the prison units commanded by the organization. In order to execute those who must be eliminated, the PCC uses more subtle and less visible mechanisms, such as hanging in order to simulate suicide - or, as most recently occurred, the gatorade. ${ }^{34}$ The simulation of suicide or death by overdose eliminates the historical problem in the prison system of the perpetrator of the crime, which was usually assumed by laranjas. ${ }^{35}$ The investigation of the conditions under which these events occur is extremely defective - if drugs are found in the nostrils or only in the throat, for example - and so these deaths are therefore classified as suicide or even as natural. This is, therefore, a more objective form of execution which is not spectacularly public, as occurred before with the decapitation, but is effective because it satisfies the needs of the punishment and, at the same time, produces the disguise for the homicide.

\section{e. The 'Democratization' of the Organization: The Establishment of Debates}

Around about 2002, two of the first leaders of the PCC were replaced by a new leader, nicknamed Marcola. He had been responsible for a

\footnotetext{
${ }^{34}$ Gatorade is a mixture of water with a large quantity of cocaine that is sufficient to induce a cardiac arrest in the subject, similar to an overdose. The cocaine is sometimes mixed with Viagra.

${ }^{35}$ Laranja [orange] or lagarto [lizard] is the name given to the inmate who confesses to crimes or disciplinary misdeeds committed by other prisoners, usually as a form of debt repayment
} 
decentralization of power and the creation of a decision-making process where everybody - brothers and companions could participate. Accordingly, any important decision to be taken - whether the establishment of a new rule, an execution or the expulsion of somebody - is 'debated' among everybody and only after this debate is the action performed. In accordance with this discourse, the term leader is no longer used because there is the denial of any type of privilege to the brothers in relation to the companions, as well as to the leadership. ${ }^{36}$ The PCC members refer to the leaders as persons that have 'more responsibility' than the others - for the maintenance of order and harmony - and that, furthermore, they are persecuted by the state, and run the risk of going to the tranca [lock up] ${ }^{37}$ at any time.

\section{DISCUSSION}

All these elements provide evidence of the dominance of the PCC in the control of the prison order and also the success obtained by the faction in the imposition of discipline on the inmates. A brief analysis of some stages of this process reveals that, in a first stage, the organization gathered material and financial instruments that allowed for the imposition of a control that, even though it had a support base in a discourse of solidarity and union among the inmates, held a central instrument in the threat of violence. This control also had an essentially personal character, dependent on the charisma and the willingness to kill of the local leaders. Nowadays, however, the power exercised by the PCC exceeds the individuality of these leaders, inasmuch as the decisions are no longer taken in isolation by them, as they were previously. The punishments are now imposed by and on behalf of the organization, surpassing all the personal issues and the characteristics of isolated leaders. The PCC has established itself as a mediator of the social conflicts above the parties, the holder of the prerogative to

\footnotetext{
${ }^{36}$ The whole of this discourse, whose general aspects were presented here - of the inexistence of leaders, of equality for all, collective participation in the definition of rules of conduct and the application of punishment - can also be found in a statement by Marcola to the Comissão Parlamentar de Inquérito CPI (Parliamentary Investigation Committee) on the trafficking of weapons, held in 2006.

${ }^{37}$ Tranca [lock up] is the term used to refer to units that practice the RDD, and also to Presidente Venceslau I (designed for the application of punishment, where inmates can only be held for 30 days) and Venceslau II, which has stricter regime than the other penitentiaries, but is significantly more flexible than the RDD. This unit currently houses the entire leadership of the organization and, for this reason, is called the 'Park of the Monsters'. Upon the identification of a very expressive and potentially negative leadership - the definition of being a negative leader is not clearly expressed - many prison units seek the transfer of the aforesaid inmate to there. As a consequence, Venceslau II has a population of almost 800 prisoners, all of whom are considered as 'leaders' of the PCC.
}

safeguard the observance of rules and to impose the punishment on its transgressors, thereby completing the process of withdrawing from individuals the possibility of resolving their own conflicts.

In this new form of exercising power, the PCC fully uses the potential of each individual inmate, companion or brother. Foucault's approach allows us a positive understanding of the relationships established between the PCC and the incarcerated mass submitted to it, i.e. as an exercise of power with political and economical objectives, and not only repressive objectives. Economic objectives inasmuch as it mobilizes an army of men to work in the business generated by the organization; political objectives because the obedience guarantees its dominance and the consolidation of its control, which is used as a bargaining element in agreements and negotiations with the public authorities.

This is how, having consolidated its control, the PCC is able to manage and control precisely the life of the incarcerated population with far less visible violence. Therefore, it achieves its goals and, at the same time, further legitimizes its power through a discourse that affirms its responsibility in the reduction of violence inside and outside of the prison system, with the significant reduction of the number of deaths in the prisons and of murders in the outskirts of the cities. This is a discourse of legitimization of the organization that evidently only partially corresponds to the reality of the São Paulo prisons. On the one hand, it is true that there has been a reduction in the number of deaths and of law breaking in the prisons. However, it is evident that the incarcerated population is now under the control of the PCC and that the certainty of punishment for any lapse is so strong that these individuals know that they cannot transgress, in any manner. Is this connection, the psychological controls are more effective than the physical controls (Foucault, 2003).

As we have seen before, one of the traits of the domination exercised by the PCC is the reduction of the symbolic and more visible aspects of the violence imposed on those to whom it is submitted and the establishment of a discourse that seeks to disguise the despotic nature of this domination by constructing an image of an organization based on democratic forms of participation for the inmates. However, if the PCC is given the prerogative to abstain from demonstrating its strength and its power within the prisons, this is because its control is so consolidated and so 
consistent that it is no longer necessary to eliminate its adversaries in a public demonstration of its strength.

Both the increase in the number of rebellions and murders in the period from 1994 to 2006, and the fall in these events from the middle of 2006, should be understood as a product of the reconfiguration of the power in the São Paulo prison universe. This reconfiguration took place with the expropriation from individuals of the capability to use physical force and the progressive centralization of the use of violence by the PCC, as it expanded.

The violence acquires a form and a special function in each stage of this process. At the time of the expansion and consolidation of the PCC (1993-2006), the violence was established as an instrument for the conquest and demarcation of territories with the need to eliminate those who refused to accept its control, as well as having a symbolic character of demonstration of power. With the consolidation of the dominance of the PCC, the need to make the violence spectacular became unnecessary and counterproductive. This is because the management of the incarcerated population through a legitimizing discourse and the strict control of the conduct and of the activities developed in the areas managed by the group proved much more effective. The segregation, the exclusion or a 'chat ${ }^{38}$ are punitive forms practiced against those that 'trip' over the smallest detail, in the most elementary rule of conduct established by the PCC. These punitive forms guarantee obedience to its rules without the need, necessarily, of using physical violence, although this is always an omnipresent possibility.

How can one explain the transformation in the form of exercise of the power of the PCC, which implies a new manner of use of the violence? We understand that this change, which began to take shape in 2003 , but only became effective at the end of 2006, is due to several factors, most of them circumstantial, inside and outside of the organization. We shall present below some aspects that will help to understand these transformations.

\footnotetext{
${ }^{38}$ The PCC members constantly refer to the 'chat' that takes place with individuals that transgress any of the imposed detailed rules of conduct. In spite of our insistence on learning about the contents and the form of this "chat", they were always very evasive. However, we had an opportunity to interview an inmate who was safe and who had been submitted to this procedure one month earlier, having been accused of being an informer in the prison unit. The aforesaid prisoner was seen to be extremely terrorized by the humiliation, the aggression - spat on in the face, a knife pointed to his belly and a rope around the neck of the companion found in the same situation and the threats received during the 'chat'.
}

One of them refers to the administrative changes in the distribution of the prisoners into specific prisons. The São Paulo penitentiary administration began to designate specific penitentiaries for those accused of sex crimes because these inmates were the main targets of the prison population. They were constantly tortured and their death was certain when the opportunity presented itself, such as when there was a rebellion. Furthermore, members of rival factions began to be identified and separated into different prisons. Finally, the management of the prison units began to act quickly in order to transfer the inmates that requested personal protection (safety).

Secondly, there was the consolidation of the power inside the prison universe. The absence of groups that threatened the power of the PCC allowed the development of forms of conflict regulation and the maintenance of the control that were less dependent on the public demonstrations of the ability to exercise violence.

A third aspect to be considered is the supposed agreements or accommodations with the prison administration. Most of the leaders of the organization are not under the RDD but under a far more relaxed disciplinary regime, in the Penitenciária de Presidente Venceslau II. The prison unit destined exclusively for the application of the RDD (the Centro de Readaptação Penitenciária de Presidente Bernardes) has a number of prisoners far below its capacity. Considering the fact that being part of a criminal group is a factor for the internment of the prisoner in the differentiated regime, the reduced number of individuals in such a situation seems somewhat strange. This suggests some type of agreement, even if implicit, in which as long as the PCC maintains the order and the 'peace' within the system, the administration allows its leaders to continue to occupy their positions, far from the RDD. The group continues to exercise its control over the prison population, as well as its control over the illegal activities taking place inside the prison. According to the actual members of the organization, as we have already pointed out, they keep the "white flag flying", i.e. at 'peace' in the system. This signifies the prohibition of committing murders and physical assaults. Any settlement of debts should be expressly authorized by the PCC and take place within established limits that do not unbalance the social system of the prison. Rebellions and riots, as well as the murders of penitentiary agents, take place precisely, in situations where there are serious problems in the aforesaid locations. Physical violence 
is used in a calculated manner and only when it is required to exercise control. This context allowed for the construction of a discourse of legitimization of the PCC, based on the emphasis of its supposedly pacifying, controlling and disciplinary role within the prison system.

This, together with the maintenance of the current power structure inside the PCC, results in the consolidation of the position of the current leadership. There are no important struggles that could destabilize its balance.

The consolidation of the control inside and outside the prison system, the stability of the hierarchy inside the organization, agreements with the prison administration that allow them to share control of the incarcerated population and the management of illegal businesses inside and outside of the prison and the maintenance of the main leaders being kept out of the $\mathrm{RDD}$, are important factors that allow the maintenance of this appearance of peace and that the government keeps control over the PCC. However, the PCC remains strong, organized and structured, and political but administrative changes could alter the conditions that presently allow it to keep this apparent peace.

The dominance of this group over the incarcerated mass, the forms of regulation of the social relations within the prisons and also in the territories in the outskirts that it controls, its survival despite the efforts by the government to dismantle it - are all aspects that suggest a unique operational experiment by a modality of organized crime, built inside the prisons and that became known outside of them. A path for interesting research would be to consider how to fit the PCC in the continuum proposed by Hagan (1983), and what contribution can be obtained with this example for the understanding of organized crime in the contemporary world.

\section{REFERENCES}

Adams, Robert (1994) Prison Riots in Britain and the United States. London: Macmillan Press.

Adorno, S. \& Salla F. (2007) Organized Criminality in Prisons and the Attacks of the PCC. Estudos Avançados, 61: 7-29. http://dx.doi.org/10.1590/S0103-40142007000300002

Artières, Philippe; Quero, Laurent et Zancarini-Fournel, Michelle (2003). Le Groupe D'Information sur les Prisons - archives de lutes, 1970-1972. Paris: Éditions de L'IMEC.

Balandier, G. (1982) O poder em cena. Brasília: Editora UnB.

Bauman, Zygmunt (1999) Globalização: as conseqüências humanas. Rio de Janeiro: Jorge Zahar Editor.

Clemmer, Donald (1958) The Prison Community. New York : Holt, Rinehart \& Winston, 2nd edn.
Christie, Nils (1998) A Indústria do Controle do Crime: a caminho dos GULAGs em estilo ocidental. Rio de Janeiro: Forense.

Dias, C.C. N. (2008) A igreja como refúgio e a Bíblia como esconderijo: religião e violência na prisão. São Paulo: Humanitas.

Favard, Jean (1981) Le labyrinthe pénitentiaire. Paris: Éditions du Centurion.

Favard, Jean (1987) Des Prisons. Paris: Gallimard.

Fontanaud, Daniel (ed.) (2002). La Criminalité Organisée. Problèmes Politiques et Sociaux - dossiers d'actualité mondiale, n. 874875. La documentation Française.

Foucault, M. (2003) Estratégia, poder-saber. Rio de Janeiro: Forense Universitária.

Foucault, M. (2000a) Vigiar e Punir: História da violência nas prisões. Petrópolis: Vozes.

Foucault, M. (2000b) Microfísica do poder. Rio de Janeiro: Graal.

Girard, R. (1998) A violência e o sagrado. São Paulo: Paz e Terra.

Hagan, F. E. (1983) The organized crime continuum: a further specification of a new conceptual model. Criminal Justice Review, No. 8. pp. 52-7. http://dx.doi.org/10.1177/073401688300800209

Hayner, Norman S. and Ash, Ellis (1939) The Prisoner community as a social group. American Sociological Review, 4(3):362-369. http://dx.doi.org/10.2307/2084923

HOLSTON, James. (2009) Dangerous spaces of citizenship: gang, talk, rights talk and rule of law in Brazil. Planning Theory, 8 (1): 12-31. http://dx.doi.org/10.1177/1473095208099296

Huff, R.C. (ed.) (1990) Gangs in America. Newbury Park: Sage.

Jacobs, James B. (1974) Street Gangs behind Bars. Social Problems, 21 (3): 395-409. http://dx.doi.org/10.2307/799907

Jankowski, Martín S. (2003) Gangs and social change. Theoretical Criminology, 7 (2): 191-216. http://dx.doi.org/10.1177/1362480603007002413

Jozino, J. (2005) Cobras e lagartos: a vida íntima e perversa nas prisões brasileiras. Quem manda e quem obedece no partido do crime. Rio de Janeiro: Objetiva.

Lampe, Klaus Von (2008) Organized Crime in Europe: Conceptions and Realities, Policing: a Journal of Policy and Practice, 2(1):7-17.

Lupo, Salvatore (2002) História da Máfia: das origens aos nossos dias. São Paulo: Ed. Unesp.

Maccormick, Austin H. (1954) Behind the Prison Riots. The Annals of American Academy of Political and Social Science, 293:1727.

http://dx.doi.org/10.1177/000271625429300104

Paoli, L. (2002) The paradoxes of organized crime. Crime, Law \& Social Change 37: 51-97. http://dx.doi.org/10.1023/A:1013355122531

Phillips, Coretta. (2012) "It ain't nothing like American with the Bloods and the Crips': Gang narratives inside tow English prisons. Punishment and Society, 14 (1): 51-68. http://dx.doi.org/10.1177/1462474511424683

Salla, Fernando (2007) De Montoro a Lembo: as políticas penitenciárias em São Paulo. Revista Brasileira de Segurança Pública, Ano 1, edição 1, pp. 72-90.

Salla, Fernando (2006) As rebeliões nas prisões: novos significados a partir da experiência brasileira. Sociologias, ano 8, n. 16. Porto Alegre: jul/dez, pp. 274-307.

Salla, Fernando (2001) Rebeliões nas Prisões Brasileiras. Serviço Social e Sociedade. 67:18-37.

Shrag, Clarence (1954) Leadership among prison inmates. American Sociological Review, 19(1):37-42. http://dx.doi.org/10.2307/2088170 
Souza, Fatima (2007) PCC - A facção. Rio de Janeiro/São Paulo: Record.

Souza, Percival (2006) O sindicato do crime: PCC e outros grupos. Rio de Janeiro: Ediouro.

Sykes, Gresham M. (1974) The society of captives: a study of a maximum security prison. New Jersey, Princeton University Press. $\left(1^{\text {a }}\right.$. ed. 1958).

Thrasher, Frederick M. (1963) The Gang. Chicago: The University of Chicago Press.

Useem, Bert \& Kimball, Peter A. (1987) A Theory of Prison Riots. Theory and Society, 16:87-122. http://dx.doi.org/10.1007/BF00162660
Useem, Bert \& Kimball, Peter A. (1991) States of Siege: U.S. prison riots, 1971-1986. New York: Oxford University Press.

Wacquant, L. (2001) As prisões da miséria. Rio de Janeiro, Jorge Zahar.

Weinberg, S. Kirson (1942) Aspects of the prison's social structure. The American Journal of Sociology, 47(5):717-726. http://dx.doi.org/10.1086/219003

Ziegler, Jean (2003) Os Senhores do Crime. São Paulo: Record.

Received on 05-05-2013

Accepted on 04-06-2013

Published on 28-10-2013

DOI: http://dx.doi.org/10.6000/1929-4409.2013.02.37

(C) 2013 Dias and Salla; Licensee Lifescience Global.

This is an open access article licensed under the terms of the Creative Commons Attribution Non-Commercial License (http://creativecommons.org/licenses/by-nc/3.0/) which permits unrestricted, non-commercial use, distribution and reproduction in any medium, provided the work is properly cited. 